\title{
INVENTARISASI BEBERAPA MIKROORGANISME TERBAWA BENIH PADI YANG BERASAL DARI TALANG PADANG, KABUPATEN TANGGAMUS, LAMPUNG
}

\author{
Muhammad Nurdin ${ }^{1}$
}

\begin{abstract}
Inventory of seed-borne microorganisms on paddy from District of Talang Padang, Tanggamus Lampung. This study was conducted to inventory microorganisms that infected or contaminated paddy seeds from District of Talang Padang, Lampung. Paddy seed samples were obtained by stratified random sampling method. Six villages were chosen from 28 villages, with six farmers from each village. From each farmer were collected 30 gram paddy seeds. Seventy grams seeds used as the work sample in seed health testing were obtained from 1080 gram of the composite sample. Testing method that been used were blotter test and agar test, then followed by growing-on test. Bacteria and seven genera of fungi were found to be associated with paddy seeds from this study. They were Alternaria, Fusarium. Aspergillus, Curvularia, Mucor, Rhizopus and Penicillium. Virus was not obtained in this study.
\end{abstract}

Kata kunci : inventory, microorganism, paddy, seed-borne

\section{PENDAHULUAN}

Salah satu faktor penyebab kurang maksimalnya produksi padi adalah penggunaan benih padi yang tidak bermutu. Salah satu faktor yang menentukan mutu benih adalah kesehatan benih yang ditentukan oleh ada atau tidaknya mikroorganisme terbawa benih, seperti jamur, nematoda, bakteri, atau virus (Misra et al., 1994). Benih yang sehat sangat penting dalam produksi tanaman pertanian karena benih merupakan titik awal untuk mendapatkan tanaman yang sehat. Oleh karena itu benih harus bebas dari infeksi dan kontaminasi patogen.

Kerugian yang dapat ditimbulkan oleh patogen terbawa benih adalah pertumbuhan tanaman yang kurang baik dan tersedianya sumber inokulum patogen sejak awal tanaman tumbuh di lapangan. Selain itu, mikroorganisme terbawa benih juga dapat menurunkan kualitas benih seperti menurunnya daya kecambah benih, kerusakan bentuk fisik dan warna benih, bahkan beberapa mikroorganisme tertentu tidak saja menurunkan kualitas benih, juga menyebabkan benih yang terinfeksi itu menjadi sangat beracun (Sutopo, 1993). Haryati dan Mahmud (1993) melaporkan bahwa bakteri juga yang berasosiasi dengan benih dan dapat menurunkan mutu benih dan daya kecambah serta menjadi sumber inokulum di lapangan.

Hasil penelitian terdahulu menunjukkan adanya beberapa patogen yang menimbulkan penyakit tanaman padi di lapangan dapat terbawa benih dan adanya jamur gudang yang dapat menginfeksi benih dalam penyimpanan. Beberapa jamur yang terbawa benih padi yang ditemukan di daerah Delta Upang Sumatra Selatan adalah Helminthosporium oryzae, Fusarium solani, F. moniliforme, Phoma sp., Chaetomium sp., Aspergillus spp., Alternaria padwickii, Curvularia dan Cercospora oryzae (Sutopo, 1993). Jamur-jamur itu selain dapat menimbulkan penyakit di lapangan juga dapat menurunkan daya kecambah benih. Oleh sebab itu, penelitian ini bertujuan untuk menginventarisasi mikroorganisme yang terbawa benih padi yang berasal dari Kecamatan Talang Padang

\section{METODE PENELITIAN}

Penelitian ini dilaksanakan di Laboratorium Mikologi dan Virologi Tumbuhan Jurusan Proteksi Tanaman dan Rumah Kaca, Fakultas Pertanian, Universitas Lampung pada bulan April sampai dengan September 2002.

Penelitian ini dilakukan dengan metode survei dengan sampel acak bertingkat (stratified random sampling). Pengambilan sampel benih padi dimulai dengan penetapan enam desa yang dipilih secara acak dari 28 desa yang ada di Kecamatan Tanggamus dan dari setiap desa ditentukan enam petani yang dipilih secara acak dari 60 petani. Jumlah sampel yang diambil dari setiap petani 30 gram, sehingga berat sampel benih padi total dari 36 sampel adalah 1080 gram. Setelah dicampur secara merata, 1080 gram benih menjadi sampel komposit dan dari sampel itu diambil secara acak 70 gram yang digunakan dalam uji kesehatan benih. 
Pengujian kesehatan benih padi dilakukan mengikuti metode yang telah dipublikasikan oleh ISTA (1985). Pengujian kesehatan benih dengan metode ini menggunakan dua metode, yaitu metode inkubasi dan uji gejala penyakit pasca kecambah (growing-on test). Metode inkubasi terdiri atas dua cara inkubasi, yaitu inkubasi pada kertas hisap dan inkubasi pada media agar. Benih yang nampak sehat dan berkecambah dari kedua metode itu ditumbuhkan pada pot di rumah kaca untuk mengetahui gejala penyakit pasca kecambah. Pegujian ini dilakukan untuk mendeteksi mikroorganisme yang tidak terdeteksi oleh metode inkubasi karena belum munculnya gejala pada fase benih.

Pengujian kesehatan benih pada sampel kerja 70 gram (750 butir benih) dilakukan dengan menginkubasikan benih dalam cawan perti. Benihbenih itu dibagi menjadi 30 cawan petri yang masing masing cawan berisi 25 butir benih. Pemeriksaan kesehatan benih dengan metode kertas hisap: sebelum benih dinkubasi cawan petri dialasi dengan 3 lembar kertas hisap yang dibasahi dengan air steril. Pemeriksaan metode agar pada 30 cawan petri dituang agar dekstrosa kentang. Benih dalam cawan petri dari kedua metode tersebut diinkubasikan selama 37 hari dengan penyinaran 12 jam terang (UV) dan 12 jam gelap.

Pengamatan dan identifikasi mikroorganisme yang muncul dilakukan sejak hari ke 3 sampai hari ke 7 menggunakan mikroskop binokuler dan majemuk. Selain itu juga dilakukan penghitungan persentase perkecambahan benih, frekuensi mikroorganisme dan persentase mikroorganisme yang berasosiasi dengan benih. Identifikasi jamur dilakukan sampai tingkat genus, sedangkan mikroorganisme lain hanya dicatat keberadaannya. Persentase frekuensi temuan mikroorganisme adalah jumlah cawan petri yang mengandung mikroorganisme tertentu dibagi dengan jumlah cawan petri total (30) pada setiap metode pengujian kali seratus persen. Persentase perkecambahan benih dihitung berdasarkan persentase benih yang berkecambah dibandingkan dengan total benih yang diuji, sedangkan persentase mikroorganisme yang berasosiasi dengan benih padi dihitung berdasarkan jumlah benih padi yang berasosiasi dengan mikroorganisme tertentu dibagi jumlah benih dalam setiap cawan (25) kali seratus persen.

\section{HASIL DAN PEMBAHASAN}

\section{Persentase frekuensi temuan mikroorganisme}

Hasil penelitian ini menunjukkan bahwa frekuensi mikroorganisme tertinggi adalah Alternaria baik menggunakan metode kertas hisap (90\%) maupun metode agar (93,33\%), sedangkan mikroorganisme urutan berikutnya pada kedua metode itu berlainan. Pada metode kertas hisap ditemukan bakteri (60\%), Fusarium (50\%), Curvularia (36,66\%) dan Aspergillus (10\%), sedangkan pada metode agar ditemukan Fusarium (86,66\%), bakteri (30\%), Aspergillus dan Penicillium (masing-masing 26,66\%), Curvularia (16,66 \%), Rhizopus (13,33\%) dan Mucor (3,33\%) (Tabel 1).

Tabel 1. Persentase frekuensi temuan mikroorganisme dari sampel benih padi dengan uji inkubasi metode kertas hisap dan metode agar

\begin{tabular}{lcc}
\hline \multirow{2}{*}{ Mikroorganisme } & \multicolumn{2}{c}{ Frekuensi Temuan (\%) } \\
\cline { 2 - 3 } & Metode kertas hisap & Metode agar \\
\hline Alternaria & 90,00 & 93,33 \\
Bakteri & 60,00 & 30,00 \\
Fusarium & 50,00 & 86,66 \\
Curvularia & 36,66 & 16,66 \\
Aspergillus & 10,00 & 26,66 \\
Penicillium & 0,00 & 26,66 \\
Rhizopus & 0,00 & 13,33 \\
Mucor & 0,00 & 3,33
\end{tabular}

Menurut Agarwal dan Sinclair (1987) Alternaria padwickii merupakan jamur penyebab penyakit stackburn dan hawar bibit yang terbawa benih padi. Jamur ini umumnya bertahan pada benih 
dan sisa-sisa tanaman sakit dan masuk ke dalam benih dengan cara penetrasi kulit dan menginfeksi gabah sebelum masak. Benih padi yang terinfeksi menunjukkan gejala bercak coklat sampai keputihputihan dengan tepian berwarna coklat tua dan pada pusat bercak terdapat titik-titik hitam (Semangun, 1993). Fusarium dan Curvularia merupakan patogen terbawa benih dari lapangan sedangkan Penicillium spp merupakan jamur gudang atau jamur yang menginfeksi benih setelah benih berada dalam gudang (Ou, 1985; Ali et al., 1996). Pada umumnya jamurjamur yang terbawa dari lapangan akan berada dalam keadaan dorman selama benih disimpan (Justice dan Bass, 1994) dan dapat bertahan selama penyimpanan benih (Neergaard, 1977).

Jamur yang berasosiasi dengan benih padi tidak hanya jamur yang terbawa benih dari lapangan tetapi juga jamur dari gudang, seperti Aspergillus, Penicillium, Rhizopus dan Mucor, yang keempatnya adalah jamur parasit fakultatif (Semangun, 1993). Banyaknya jamur gudang yang ditemukan dalam penelitian ini diduga berkaitan dengan benih padi tersebut sudah mengalami proses penyimpanan. Kondisi tempat penyimpanan yang lembab dan cara penyimpanan benih padi oleh petani di Talang Padang yang sederhana memperburuk kondisi kesehatan benih padi.

\section{Persentase perkecambahan benih dan persentase mikroorganisme yang berasosiasi dengan benih padi}

Hasil penelitian ini menunjukkan bahwa baik metode kertas hisap maupun media agar mikroorganisme yang dominan adalah Alternaria, Fusarium, dan bakteri. Jenis mikroorganisme yang ditemukan pada metode agar lebih banyak (8 jenis) dibandingkan dengan jenis mikroorganisme yang ditemukan pada metode kertas hisap (5 jenis), sedangkan persentase perkecambahan benih hampir sama antara kedua metode (Tabel 2).

Infeksi Alternaria, Fusarium, dan bakteri dapat terjadi sejak tanaman padi di lapangan karena ketiga mikroorganisme tersebut merupakan patogen tanaman padi dan bukan mikroorganisme gudang. Fusarium graminearum merupakan patogen hawar pucuk dan kudis tanaman padi yang terbawa benih padi. Bakteri yang sering berasosiasi dengan benih padi adalah Pseudomonas oryzicola patogen bintik gabah dan busuk pelepah, Xanthomonas campestris pv. oryzae patogen hawar daun padi serta $X$. campestris pv. oryzicola patogen daun bergaris.

Tabel 2. Rerata Persentase perkecambahan benih dan persentase mikroorganisme yang berasosiasi dengan benih padi pada uji kertas hisap dan agar

\begin{tabular}{lcc}
\hline $\begin{array}{l}\text { Perkecambahan benih } \\
\text { dan mikroorganisme }\end{array}$ & Media kertas hisap (\%) & Media agar (\%) \\
\hline $\begin{array}{l}\text { Perkecambahan benih } \\
\text { Mikroorganisme }\end{array}$ & 92,0 & 89,0 \\
$\quad$ Alternaria & 10,9 & 9,5 \\
Fusarium & 4,9 & 9,2 \\
Aspergillus & 0,4 & 1,2 \\
Curvularia & 1,7 & 0,7 \\
Mucor & 0,0 & 0,1 \\
Rhizopus & 0,0 & 0,4 \\
Penicillium & 0,0 & 1,1 \\
Bakteri & 4,1 & 2,3 \\
\hline
\end{tabular}


Jenis mikroorganisme yang ditemukan pada metode agar lebih banyak daripada jenis mikroorganisme pada metode kertas hisap, hal ini disebabkan media agar lebih kaya nutrisi sehingga mikroorganisme yang tidak dapat tumbuh pada metode kertas hisap dapat tumbuh pada metode agar. Keunggulan metode agar dibandingkan dengan metode kertas hisap juga dilaporkan oleh Agarwal dan Sinclair (1987) yang menyatakan bahwa kedua metode inkubasi biasa digunakan dalam pengujian kesehatan benih, hanya metode agar mempunyai banyak keunggulan antara lain dapat mendeteksi koloni yang tumbuh dari mikroorganisme yang terbawa benih.

Pengujian kesehatan benih lanjutan dilakukan di rumah kaca untuk mengamati kemungkinan munculnya gejala penyakit pasca kecambah dari benih yang nampak sehat. Pengujian ini hasilnya negatif, artinya tidak ada gejala yang muncul.

\section{KESIMPULAN}

Mikrorganisme yang diidentifikasi pada benih padi yang berasal dari Talang Padang, Kecamatan Tanggamus adalah Alternaria, Fusarium, Bakteri, Curvularia, dan Rhizopus, Mucor, Aspergillus serta Penicillium. Pengujian kesehatan benih lanjutan dilakukan di rumah kaca tidak menemukan gejala penyakit pasca kecambah.

\section{SANWACANA}

Terima kasih disampaikan kepada beberapa petani padi di Talang Padang Tanggamus dan Saudari M.P. Catur Kartikarini, S.P. yang telah membantu secara teknis pada penelitian ini. Kepada Bapak Dr. Ir. Hasriadi Mat Akin, M.S. terima kasih atas sumbangan pemikirannya yang berharga.

\section{DAFTAR PUSTAKA}

Agarwal, V.K. \& J.B. Sinclair. 1987. Principles of Seed Pathology. Vol.I \& II. CRC Press Inc., Boca Raton, Florida.

Ali, A.H., Z. Zainuddin \& S. Tosiah. 1996. Farmers' practices in rice seed production in Malaysia. Pp. 33-35 In : Rice IPM Conference Integrating Science and People in Rice Pest Management Kuala Lumpur, 18-21 November 1996.

Haryati, S.E. \& M. Machmud. 1993. Deteksi bakteri patogen terbawa benih padi. Hlm.: 30-33. Dalam: Prosiding Kongres Nasional XII dan Seminar Ilmiah PFI. Yogyakarta, 6-8 September 1993.

ISTA. 1985. International Rules for Seed Testing. Seed Science and Technology 13(2): 300-520.

Justice, O.L. \& L.N. Bass. 1994. Prinsip dan Praktek Penyimpanan Benih. PT Raja Grafindo Persada. Jakarta.

Misra, J.K., T.W. Mew \& S.D. Merca. 1994. Rice seed health and quarantine. In: Mew, T.W.\& Misra, J.K. (eds.). A manual of rice seed health testing. IRRI. Los Banos, Laguna, Philippines.

Neergaard, P. 1977. Seed Pathology. Vol.I. John Wiley \& Sons, New York.

Ou, S.H. 1985. Rice Disease. $2^{\text {nd }}$. Commonwealth Mycological Institute, Kew Surrey, England.

Semangun, H. 1993. Penyakit-penyakit Tanaman Pangan di Indonesia. Gadjah Mada University Press, Yogyakarta.

Sutopo, L. 1993. Teknologi Benih. PT Raja Grafindo Persada, Jakarta. 
J. Hama dan Penyakit Tumbuhan Tropika

Vol. 3, No. 2: 47-50 (2003). ISSN 1411-7525

${ }^{1}$ Dosen Jurusan Proteksi Tanaman, Fakultas Pertanian Universitas Lampung 